See Article page 1549.

\section{Commentary: The jury is out- expanding eligibility for lung transplantation after hematopoietic stem cell transplantation}

\author{
Samantha E. Halpern, BA, ${ }^{a}$ Samuel J. Kesseli, MD, ${ }^{b}$ \\ and Matthew G. Hartwig, MD, MHS
}

Over the last 30 years, early mortality after allogeneic hematopoietic stem cell transplantation (HSCT) has declined, with a consequent increase in long-term morbidity. ${ }^{1}$ Among late post-HSCT complications are noninfectious pulmonary complications, including bronchiolitis obliterans, which typically occur within 2 years after HSCT and portend a 5 -year survival probability of $<15 \%{ }^{2,3}$ Medical management is of limited efficacy in this setting, and lung transplantation (LTx) has emerged as a potential therapy for select patients. ${ }^{3-5}$

Presently, only $1 \%$ of LTx are performed for bronchiolitis obliterans unrelated to previous LTx; of those, cases related to HSCT represent only a subset. ${ }^{5,6}$ To maximize the utility of a scarce resource, LTx is offered to patients at high risk of lung disease-related mortality, without comorbidities that may compromise posttransplantation survival. ${ }^{7}$ As HSCT recipients remain at risk of recurrence of their original malignancies, the International Society for Heart and Lung Transplantation lists hematologic malignancy within the past 2 years, and conservatively within the past 5 years, as a contraindication for LTx. ${ }^{7}$ Nevertheless, post-LTx recurrence seems to be rare, affecting $2 \%$ to $7 \%$ of HSCT recipients. ${ }^{5,8,9}$ As such, revisitation of eligibility for LTx after HSCT may be warranted to meet rising needs.

\footnotetext{
From the ${ }^{a}$ School of Medicine, Duke University, Durham, NC; and ${ }^{b}$ Department of Surgery and ${ }^{\mathrm{c} D i v i s i o n}$ of Cardiovascular and Thoracic Surgery, Department of Surgery, Duke University Medical Center, Durham, NC.

Disclosures: The authors reported no conflicts of interest.

The Journal policy requires editors and reviewers to disclose conflicts of interest and to decline handling or reviewing manuscripts for which they may have a conflict of interest. The editors and reviewers of this article have no conflicts of interest.

Received for publication Nov 19, 2020; revisions received Nov 19, 2020; accepted for publication Nov 20, 2020; available ahead of print Nov 30, 2020.

Address for reprints: Matthew G. Hartwig, MD, MHS, Division of Cardiovascular and Thoracic Surgery, Department of Surgery, Duke University Medical Center, Box 3863, Durham, NC 27710 (E-mail: matthew.hartwig@ duke.edu).

J Thorac Cardiovasc Surg 2022;163:1561-2

$0022-5223 / \$ 36.00$

Copyright (c) 2020 by The American Association for Thoracic Surgery

https://doi.org/10.1016/j.jtcvs.2020.11.103
}

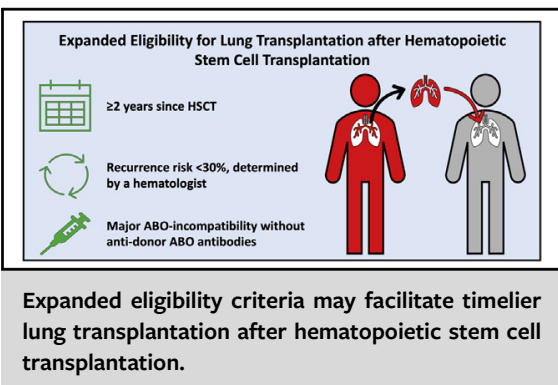

CENTRAL MESSAGE

Consideration of recurrence risk

may facilitate lung transplanta-

tion after hematopoietic stem

cell transplantation. Further

study is needed before advo-

cating for new lung transplanta-

tion criteria in this setting.

In this issue of the Journal, Noguchi and colleagues ${ }^{10}$ present novel eligibility criteria for LTx after HSCT, and outcomes among 40 patients transplanted under their protocol. At their institution, HSCT patients may undergo LTx if the risk of recurrence is considered to be $<30 \%$; for deceased donor LTx, transplantation may occur 2 years after HSCT, whereas living donor lobar LTx (LDLLT) is permitted within 2 years. As HSCT alters patients' ABO blood types to those of corresponding bone marrow donors, post-HSCT LTx is further facilitated by tolerance of major $\mathrm{ABO}$ incompatibility in the absence of antibodies to donor blood group antigens. Their results demonstrate comparable 5-year post-LTx survival among HSCT and non-HSCT patients, and among HSCT patients with disease-free interval $>5$ years or $<5$ years. No recurrences were documented during a median 4 years of follow-up.

These eligibility criteria for LTx after HSCT are intriguing for several reasons. First, compared with current guidelines, this protocol allows HSCT recipients to undergo LTx sooner, potentially mitigating severity of lung dysfunction at transplantation. Second, the use of ABOincompatible donors may offer a novel means by which to expand the donor pool. However, wide applicability of their findings remains uncertain. In particular, 32 of 40 patients in their cohort underwent LDLLT owing to a paucity of deceased organ donors in Japan. In other countries, however, LDLLT represents the vast minority of LTx. ${ }^{11}$ Although previous studies have shown comparable outcomes among HSCT and non-HSCT deceased donor LTx recipients, 
the utility and safety of new eligibility criteria for LTx require further investigation in this setting.

In conclusion, the jury is out on expanding eligibility for LTx to HSCT recipients, but Noguchi and colleagues offer a thoughtful new paradigm for evaluating the optimal provision of lung grafts in this population.

\section{References}

1. Styczyński J, Tridello G, Koster L, Iacobelli S, van Biezen A, van der Werf S, et al. Death after hematopoietic stem cell transplantation: changes over calendar year time, infections and associated factors. Bone Marrow Transplant. 2020;55:126-36.

2. Williams KM, Chien JW, Gladwin MT, Pavletic SZ. Bronchiolitis obliterans after allogeneic hematopoietic stem cell transplantation. JAMA. 2009;302:306-14.

3. Haider S, Durairajan N, Soubani AO. Noninfectious pulmonary complications of haematopoietic stem cell transplantation. Eur Respir Rev. 2020;29:190119.

4. Chi AK, Soubani AO, White AC, Miller KB. An update on pulmonary complications of hematopoietic stem cell transplantation. Chest. 2013;144:1913-22.

5. Greer M, Berastegui C, Jaksch P, Benden C, Aubert J, Roux A, et al. Lung transplantation after allogeneic stem cell transplantation: a pan-European experience. Eur Respir J. 2018;51:1701330.
6. Yusen RD, Edwards LB, Dipchand AI, Goldfarb SB, Kucheryavaya AY, Levvey BJ, et al. The registry of the International Society for Heart and Lung Transplantation: thirty-third adult lung and heart-lung transplant report2016; Focus theme: primary diagnostic indications for transplant. J Heart Lung Transplant. 2016;35:1170-84.

7. Weill D, Benden C, Corris PA, Dark JH, Davis RD, Keshavjee S, et al. A consensus document for the selection of lung transplant candidates: 2014an update from the pulmonary transplantation Council of the International Society for Heart and Lung transplantation. J Heart Lung Transplant. 2015;34: $1-15$.

8. Holm AM, Riise GC, Hansson L, Brinch L, Bjørtuft $\varnothing$, Iversen M, et al. Lung transplantation for bronchiolitis obliterans syndrome after allo-SCT. Bone Marrow Transplant. 2013;48:703-7.

9. Soubani AO, Kingah P, Alshabani K, Muma G, Haq A. Lung transplantation following hematopoietic stem cell transplantation: report of two cases and systematic review of literature. Clin Transplant. 2014;28: 776-82.

10. Noguchi M, Chen-Yoshikawa TF, Arai Y, Kondo T, Ohsumi A, Nakajima D, et al. Expanded indications for lung transplantation for pulmonary complications after hematopoietic stem cell transplantation. J Thorac Cardiovasc Surg. 2022;163: 1549-57.e4.

11. Patterson GA. Living lobar lung transplantation: is it a necessary option? Am J Transplant. 2004;4:1213-4. 